\title{
APPLYING THE ACTUAL/POTENTIAL PERSON DISTINCTION TO REPRODUCTIVE TORTS ${ }^{1}$
}

\begin{abstract}
As technology has advanced the level of control that can be exercised over the reproductive process has increased. These advances have resulted in a number of claims in tort law relating to pregnancy and birth. The three reproductive torts considered here are 'wrongful conception', 'wrongful birth' and 'wrongful life'. This paper will consider the theoretical underpinnings upon which these torts rest, and will suggest that the potential/actual person distinction is crucial to these reproductive torts because potential persons should not be able to make claims in tort based on alternative conditions that could never have been. This is because actions (or omissions) prior to birth determine the pre-conditions for existence. Thus, only actual persons (that is those who exist at the time of the action or omission) should be able to bring claims in tort. The analysis will conclude by arguing that no child should be permitted to bring a claim under any form of reproductive tort.
\end{abstract}

\section{Introduction}

The main purpose of this work is to consider the implications of acknowledging the potential/actual person distinction in relation to legal claims relating to reproductive torts. This entails consideration of what constitutes a 'person' and what impact decisions in this area will have upon the existence and identity of potential persons. The discussion

\footnotetext{
${ }^{1}$ The term Reproductive torts originates with Nicolette Priaulx's work and encompasses all three terms; wrongful life, wrongful birth and wrongful conception. While these are distinct terms and all fall within negligence for the purposes of this analysis 'reproductive torts' is a useful term to identify these particular claims.
} 
in this paper will be anchored around a discussion of the reproductive torts of wrongful birth/conception and wrongful life claims. For the sake of simplicity, wrongful birth and wrongful conception will be discussed together because they both relate to parental claims rather than children claiming. These torts have been selected because the very basis of these claims relates to the existence and identity of a person, who would not have existed but for the action giving rise to a tort claim. Collectively these torts deal with actions that cause an individual to exist. Furthermore the reproductive torts of wrongful conception, birth and life are pertinent to discussing liability for reproductive actions because they intersect with claims between parents, offspring and third-party medical providers. Reproductive torts thus provide a suitable context within which to discuss the potential/actual distinction, psychological personhood and the implications for legal reform.

The format of this article will be as follows. Firstly it will provide an outline of why the potential/actual person distinction is important and what that implies for how we think of decisions that create new individuals. This will be followed by a section assessing the construct of psychological personhood, which is important because it highlights that changes occurring before a potential person becomes an actual person creates new individuals rather than changing the conditions for a pre-existing one. This argument is based upon the fact that different psychological characteristics create different people and that this is affected by both mental and physical changes to an organism. Thus, prior to actual existence no person exists and changes to the conditions in which offspring will be produced are creating new persons. Together these two related concepts of potential/actual persons and psychological personhood will serve as a platform for reassessing reproductive torts and in suggesting the direction reform of the law should take. Essentially the claims will be as follows; potential persons have no 
claims on the actions of actual persons and only the interests of actual persons can sustain claims in tort.

As we consider the reproductive torts of wrongful birth/conception and wrongful life we will see how the courts have encountered the problems which the theoretical section on potential/actual persons and psychological personhood expose. In further support of the integral nature of the problems with reproductive torts, other nonUK jurisdictions will be brought into the discussion. For the sake of clarity, the differences between the reproductive torts under consideration will be explored in the brief description of each 'tort' that follows.

'Wrongful conception' - Wrongful conception cases concern the birth of a healthy child where the very conception of a child was something that the parents had actively sought to prevent (for example by undergoing a vasectomy which was carried out incorrectly, so that the parents now have a child which they never intended to have ${ }^{2}$. 'Wrongful birth' cases occur when a child has been conceived and the parents are given incorrect advice or information regarding the condition of the foetus, where such advice if given non-negligently might have led to a termination ${ }^{3}$. These cases also include situations where some action by the medical professional causes a disability to occur or damages the foetus ${ }^{4}$. Normally these reproductive torts are relatively straight forward claims by existing persons (the parents), that they have been harmed because the medical procedure was carried out incorrectly and resulted in the birth of a child, with or without a disability.

However in the UK there is an aberrant situation under s.1 of the Congenital Disabilities (Civil Liabilities) Act 1976 ('CDCLA') which allows a child to claim under the

\footnotetext{
${ }^{2}$ MacFarlane v Tayside Healhboard [2000] 2 AC 59.

${ }^{3}$ Farraj v King's Healthcare NHS Trust [2010] 1 W.L.R. 2139.

${ }^{4}$ Whitehouse v Jordan [1981] W.L.R. 246.
} 
tort of wrongful birth when the actions of a medical provider lead to the child having disabilities that it otherwise would not have. It is important to note that this does not allow claims by healthy children; it only allows claims under wrongful birth in cases of disability caused by medical providers. In this respect wrongful birth claims under the CDCLA are somewhat similar to the wrongful life cases.

'Wrongful life' - The tort of wrongful life is a claim by a child that they should not have been caused to exist at all. In essence offspring claim that life is so intolerable and full of inescapable suffering that they are better off not existing rather than being born in such a state. The courts are thus asked to conclude that being born was harmful to the child and that non-existence was a better condition, of which they have been deprived. The term wrongful life is not without controversy as Kirkby $\mathrm{J}$ in the Australian case of Harriton $v$ Stephens demonstrates. Kirby J stated that in his view "its use, even as a shorthand phrase, should be avoided" ${ }^{5}$. Kirkby J takes this view for a number of reasons, but the most important of them are as follows; the phrase wrongful life "denigrate[s] the value of human existence" and that by "lumping all such cases under the one description there is a danger that important factual distinctions will be overlooked or obscured" Kirkby J prefers the term 'wrongful suffering' as it encapsulates, what Kikby J sees as the basis of the claim, that the "negligence ... has directly resulted in the present suffering"? In line with judicial terminology the phrase wrongful life will be retained in this article, although as we will see, in addition to the just stated objection, this term has different interpretations in different jurisdictions.

\footnotetext{
${ }^{5}$ Harriton v Stephens [2006] Unreported Cases High Court of Australia at [8].

${ }^{6}$ Harriton [2006] at [11]

${ }^{7}$ Harriton [2006] at [10]
} 
However, this raises the philosophical problem of comparing existence with nonexistence which is conceptually impossible because non-existence is the absence of everything. There is thus no-one who is better off than the child that does exist. This is also a legal problem for the courts as they cannot (and are not prepared to) calculate damages on this basis and are unwilling to countenance the idea that non-existence could be preferable to life ${ }^{8}$. Currently, such claims are not permitted under UK law ${ }^{9}$ and, as we shall see, other jurisdictions have struggled with the wrongful life tort. In the New Jersey case of Gleitman v Cosgrove $[1967]^{10}$ the court found that a wrongful life claim could not be actionable, while in the state of California the case of Curlender v Biosciences Laboratories $[1980]^{11}$ held that a wrongful life claim was sustainable. It is thus by no means a settled question as to whether wrongful life claims can be judicially recognised.

Moreover, wrongful birth and wrongful life actions can be distinguished as claims brought by parents and claims brought by the offspring themselves respectively ${ }^{12}$, however this division on the basis of the identity of the claimant does not always apply, as we have seen from the CDCLA. Throughout this article, these reproductive torts are separated by type (that is wrongful birth/conception and wrongful life) rather than on the basis of who brings the claim. It should, however, be borne in mind that who can claim, normally, follows the pattern of 'wrongful conception/birth' claimants being the parents, while 'wrongful life' claimants are the children (or someone acting on behalf of the child); but this is not always the case and sometimes the claimants will be different as under the CDCLA.

\footnotetext{
${ }^{8}$ McKay v Essex Area Health Authority [1982] Q.B. 1166

${ }^{9}$ McKay [1982]

${ }^{10}$ Gleitman v Cosgrove [1967] 49 N.J. 22

${ }^{11}$ Curlender v Biosciences Laboratories [1980] 165 Cal. Rptr. 477.

${ }^{12}$ Harriton at [11]
} 
Reproductive torts relate to harms and damages that the law recognises to offspring where the action has occurred before their birth, and covers both parents and the child claiming against a medical provider. The law can therefore recognise that harms can occur before a legal person comes into existence and that once the child exists their claim crystallises allowing a claim in tort. However the conclusion of the paper will be that children can never claim for the condition they are born in, regardless of what state that is or how it was caused. This would require the removal of section one of the Congenital Disabilities Act which allows children to claim under wrongful birth cases, and retain the non-recognition of wrongful life torts. This conclusion will be based upon the fact that decisions and conditions which constitute the new person cannot be grounds for claims that they either should have existed in a different condition or should not exist at all, because in both cases they (the person claiming) would not exist and thus they would not be affected. This line of reasoning is 'person-affecting' in its approach, which dovetails with tort law as tort requires that a person is in a worse condition than they otherwise would be; that is a person is affected by the wrongful conduct ${ }^{13}$.

This conclusion would apply whether the conduct comes from medical providers, prospective parents or genetic engineers (whether through genetic selection or modification) thus only allowing for the interests of actual persons to determine the decisions made. Therefore the legal claims of reproductive torts will not be able to be based upon harm to the not-yet-existing offspring but would have to be based upon the effects of their actions on actual persons.

\footnotetext{
${ }^{13}$ C. Elliott and F. Quinn Tort Law (Longman, 2011) p.375.
} 


\section{The potential/actual distinction ${ }^{14}$ and psychological personhood}

The importance of the potential/actual person distinction cannot be overstated because it speaks to the difference between those who can suffer harm or gain some benefit and those whose very existence is constituted by the decisions being undertaken. It is important because the basic aim of tort law, including reproductive torts, is to put someone in the situation they would have been in if the tortious action had not occurred $^{15}$. The problem with reproductive torts is that the situation before the tort occurred is non-existence, and thus a comparison between existence and non-existence is required to calculate damages. As Ackner LJ states "how can the court begin to evaluate non-existence ... No comparison is possible and therefore no damage can be established which a court could recognise" (MacKay v Essex Area Healthboard [1982] at p.1189). Thus we do not have to consider whether we take a person-affecting or impersonal approach to harm, because tort presupposes that persons are affected. We therefore must be able to identify who the person affected is and we must know how they were affected and what condition they would have been in prior to the action.

We can thus see why the potential/actual person distinction is important. Decisions which create persons cannot be subject to considerations of harm and benefit in relation to the person yet to exist, because the very conditions for affecting persons require that they actually exist and potential persons do not fulfil this requirement. Moreover if, as in the case of reproductive torts, the action which is complained of did not occur then the person would never have existed and thus there would be no 'person' in a better or worse condition. As David Heyd puts it, the "confusion created by wrongful life cases arises precisely from the fact that the wrongful act is the direct cause

\footnotetext{
${ }^{14}$ The potential/actual distinction is a concept that arises in across the literature. See D. Heyd, Genetbics (University of California Press, 1992); A. Giubilini and F Minerva 'After-birth abortion: Why the baby should live?' (39)5 J Med Ethics 261.

${ }^{15}$ Elliott Quinn, Law p.375
} 
of the plaintiff's existence"16. Although Heyd is speaking only in relation to the tort of wrongful life, this paper will argue that the person-affecting requirement of tort is never satisfied in reproductive cases when the child brings the claim. This is because potential persons do not exist, and as such changes to the embryo's genetic make up or physical body do not change anyone; rather they alter the genesis conditions which create a person. For example, changing whether an embryo has a disability will not change the (potential) person who will exist because no one exists, it will only change the conditions of the creation process.

Additionally the existential status of potential persons means that they also fail to fulfil the need for a single relationship. As Ernest Weinrib states tort law, as a component of corrective justice, "treats the doer and the sufferer of harm as the active and passive participants in a single relationship" ${ }^{17}$. Thus the legal relationship required in tort claims is absent because of the necessary requirement of existence for there to be a doer and sufferer, a harm and a harmed.

\section{What are psychological persons?}

This paper adopts a psychological personhood approach to the nature of persons and personal identity which will now be outlined. The concept of psychological personhood is a claim that can be summarised as; persons exist only as an aggregate or a construct of the mental capacities of organisms, they do not exist outside of this realm. Thus a person is not a person because they are biologically human, or because they possess a name, but because they have certain psychological features of memory, self-awareness, a sense of self over time, desires and interests between the past, the ongoing now and future

\footnotetext{
${ }^{16}$ D. Heyd, Genethics p.29.

${ }^{17}$ E. Weinrib ‘The Jurisprudence of Legal Formalism’ Harvard Journal of Law and Public Policy 16 (1993) 583, p.588.
} 
instants ${ }^{18}$. These features then give rise to psychological connectedness (connections between one instant and the next) and together form psychological continuity between past, present and future ${ }^{19}$. Lynne Baker identifies the crucial attribute of a person as the 'First-Person Perspective' (FPP) in which a being can think of itself as the source of thoughts and desires ${ }^{20}$. This is a good means of identifying a person and provides a continuous sense of identity within the entity that is a person. The content of personal identity, that is, of a person being a particular someone and having specific goals and desires is provided by the other psychological features of experience and memory. Thus the FPP provides a sense of unity over life and experience, but FPP relies on connections and continuity between instants and experiences to provide personal identity. Personal identity is therefore the narrative of a specific person's existence, while being a member of the group of beings called 'person' is dependent on the capacity for a First-Person Perspective. If these connections are absent, then psychological personhood would suggest that someone is not the same person over time even if they remain the same physical organism. This allows for a self-referencing narrative which builds a biographical life, gives meaning and purpose of a person's life and makes a life plan constructed through projects ${ }^{21}$ possible; this self-recursive construction is what distinguishes a person from a non-person.

This starkly contrasts with how we normally think of ourselves. As a consequence, the importance of psychological attributes is greater than under alternative theories of persons (such as the view of persons being an indestructible soul or being a human organism). Furthermore, it means that persons are fundamentally the font of

\footnotetext{
18 J. Locke, An essay on buman understanding (1690); D. Parfit Reasons and Persons (Clarendon Press, Oxford 1984) pp.204-209.

${ }^{19}$ D. Parfit, Persons pp.204-209.

${ }^{20}$ L. Baker Persons and Bodies (Cambridge University Press, 2000) p.64.

${ }^{21}$ L. Lomasky Persons, Rights and the Moral Community (Oxford University Press, 1990) p.32.
} 
value and for things to be 'good' or 'bad,' a person must actually exist. An actual person who exists can be affected by things that happen around and to them, and thus can make a value judgement regarding those actions. Potential persons cannot be affected in a similar manner because the necessary condition for them to evaluate the effect of things is that they exist, but it is their very existence which is being decided.

Thus Heyd can state that "they [potential persons] do not meet certain preconditions of existence and identity" 22 , and consequently as we modify and change an embryo (that is, as we change the conditions for the potential person's existence) we will be creating a new person, not altering the circumstances for the same person. If this were not the case, for example, if person were 'souls', then reproductive torts would be sustainable, as the existence of the person would be prior to the existence of their body. However, in this case, every negative attribute would be included in a tort claim because these would all be affecting someone and would be making things worse for them. In the case of psychological persons, the person develops after their body, thus actions which occur prior to their existence are excluded from affecting them because these actions constitute the person who will exist.

This theoretical platform means that actions giving rise to reproductive torts will lead to a new person coming into existence regardless of what these actions are. Thus medical providers causing a disability to occur in an embryo will simply be changing the constituting conditions of a new potential person. Similarly wrongful conception results in a new potential person who would not otherwise exist. Equally, failing to diagnose a disability that would lead to the parents terminating the pregnancy would also be creating a new person. In both scenarios, no-one is being made better or worse off, no-one is being replaced with a different person; rather each scenario creates a new person,

\footnotetext{
${ }^{22}$ Heyd, Genethics p.36.
} 
generating a new personal identity from the specific constituting conditions. As wrongful life claims would have seen an actual person not come to exist, potential persons have no claim upon actual persons and wrongful life claims must be rejected. But we will now consider opposing views to this theory.

\section{Potential persons and the 'right' to be born (healthy)}

Having set out the argument for reforming reproductive torts by eliminating claims made by the child themselves, it is only fair that some counter claims arguing that potential persons have interests are considered. The obstacle that must be overcome in order for potential persons to have any interests or rights over actual persons is the potential/actual distinction, because it is this divide that precludes claims based upon actions that affect the constituting conditions of a person's existence.

So how then can interests and rights translate across the potential/actual divide? Loren Lomasky suggests that harms that affect a future person, but which are caused before the person exists can give rise to a retroactive complaint. This is because actual persons can recognise "goods-for-the-child [or potential person] that others have reason to acknowledge and respect" 23 , and recognise that the future person is "identifiable as a distinct individual upon whom one can act for better or ill’"24. Walter Glannon suggests that we can "prevent actual (future) people from experiencing pain and suffering and thereby avoid defeating their interests in having healthy lives" ${ }^{25}$. Moreover, Jonathan Glover states that "the parental desire for a healthy child fits with the interests of the child born as a result of the choice" ${ }^{26}$. These statements suggest that we can both identify

\footnotetext{
${ }^{23}$ Lomasky, Community at p.161.

${ }^{24}$ Lomasky, Community at p.161.

25 W. Glannon ‘Genes, Embryos and Future People,' Bioethics 12(2002) pp.187-211, p.193.

${ }^{26} \mathrm{~J}$. Glover, Choosing children: Genes, disability and design (Oxford University Press, Oxford 2008) p.42.
} 
the person who will exist and extrapolate from that things which are/will be good for them.

Lomasky claims that recognising 'good-for-someone' and being able to identify them provides a way to identify harms (over which we have control) for future persons thus we should act to prevent these harms occurring. In other words, because offspring will become persons who are now identifiable and we can predict the impact of our actions on this future person we are subject to their interests. Similarly Glover and Glannon claim that a potential person has an interest in being born in a healthy condition. It thus seems that, to Glover at least, once a conception occurs we can identify some interests of the future person. Glover names, for example, an interest in being "able-bodied and healthy" ${ }^{27}$. Therefore "the interests of the child should set limits to what potential parents do" 28 .

Glover's approach seems to satisfy Lomasky's identifiable individual requirement, it therefore seems that a potential person can in some sense be an identifiable subject. This is, however, an error because potential persons are not subjects; that is, they (a potential person) cannot be affected by actions which will constitute their conditions of existence. When we consider how these changes would be brought about we can see the claims above do not work. If we cannot change the 'health' of an embryo, then the potential person can only exist in an 'unhealthy' condition. If we can change an embryo to be healthy then it would change the constituting conditions of the person being created and thus would not be affecting them because we are creating a new person, making the 'identifiable' individual no longer identifiable. Thus "we can affirm that people cannot logically have a right to any genetic endowment, if that constitutes their

\footnotetext{
${ }^{27}$ Glover, Design at p.42.

${ }^{28}$ Glover, Design p.43.
} 
identity" ${ }^{29}$. Health, amongst many other (and possibly all) attributes, changes the conditions constituting the potential person, such that each change is a fresh act of creation.

It could be claimed that embryos do have interests which only crystallise once they become a person. Yet this makes no logical sense for the same reason that both Glover and Glannon's 'interest' and Lomasky's 'good-for' approaches cannot work; because each approach requires a subject who benefits from the good or interest. However, the persons who supposedly possess these interests or for whom the goods are good-for are constituted by such decisions; that is, the conditions for being benefited or harmed require a person, a subject to exist, in order to determine value to that person. Just as there is no basis for saying that being brought into existence is a benefit, because no subject exists who is waiting to be alive, it cannot be claimed that a potential person is benefited by being born in a particular condition. And "for the same reasons, we cannot hold the child is ... an object of maleficence" 30 ; in other words, a potential person who becomes an actual person cannot be benefited or harmed by decisions which create and cause them to exist. There are no exceptions to the statement that potential persons cannot be harmed by being caused to exist; only actual persons have interests which can be harmed and thus any regulation has to be based, and can only be based, upon the interests of extant persons.

\section{The importance of reproductive torts}

We can now turn to the changes and impact that reproductive torts would have to undergo in order to conform to the idea that potential persons have no claim over actual persons. Allowing parents (actually existing persons) to claim creates no difficulty at all

\footnotetext{
${ }^{29}$ Heyd, Genethics p.172.

${ }^{30}$ Heyd, Genethics p.109.
} 
because they have interests that can be affected by the actions which lead to the existence of offspring. On the other hand, allowing children who result from actions which create them to claim against someone for acts or omissions causing their existence causes a great deal of difficulty. Reproductive torts would need to be reformed because it is logically impossible for a child to be harmed or benefited by actions which create them. Furthermore as we have seen the necessary relationship between the person who causes the harm and the person who suffers the harm is absent, because both parties must be in a "single [correlative] relationship" ${ }^{31}$. It is thus unjust for medical providers to be held as having harmed someone when this cannot be the case. Moreover, if it is the action which created the individual that is harmful then this applies regardless of whose action it is; thus if parents decide not to abort or prevent conception (where they have had accurate medical advice) then they are as much to blame as medical providers and should be liable under reproductive torts. As we will see when considering the United States case of Curlender v Bio-Science Laboratories ${ }^{32}$, the logical permissibility of a child suing their parents has been raised in court before. As Rosamund Scott has highlighted however, allowing offspring to claim against their parents would be problematic, not only because of the intra-family conflict that might arise, but because it will also "come up against a woman's very personal moral interests in self-determination" ${ }^{33}$. This of course is not a bar to the possibility of allowing offspring to claim against their parents, but explains why we should avoid it.

Even with these concerns put to one side, reproductive torts still face great difficulty in terms of agreeing a basis for calculating damages. As mentioned at the beginning of this paper, the fact that no-one can be better off than the child who actually

\footnotetext{
${ }^{31}$ Weinrib, Formalism, p.588.

32 Curlender v Bio-sciences Laboratories [1980] 165 Cal. Rptr. 477.

33 Scott 'Reconsidering "Wrongful Life" in England after Thirty Years: Legislative Mistakes and Unjustifiable Anomalies' Cambridge Law Journal 72:1 (2013) pp.115-154 at p.148.
} 
exists now means that the calculus of damages is impossible to determine. There is no better or worse situation for the child bringing the claim, because "nonexistence is not a state that can be given a value" ${ }^{34}$. This means that determining the condition the child would have been in (and thus being able to determine the damage caused) is not possible. It is clear that the law needs to be changed to end these confusions and contradictions, in particular the injustice of assigning liability to some parties involved in the creation of people (the medical providers) while exempting others from fault (the parents), and for creating liability for a harm that does not occur.

Further problems in the UK arise from the CDCLA granting locus standi to disabled children to sue the medical provider who caused the disability. Some have claimed that this is discrimination against people with disabilities as it treats disability as harm ${ }^{35}$. Now obviously it cannot be discrimination because the foetus that would be aborted is a potential person and so cannot be discriminated against; that is, there is not subject of discrimination. But what the approach mooted here does make clear is that the existence of a disability cannot be treated any differently from a 'normal' foetus. In other words, disability cannot be conceived of as harming the potential person. Moreover, by adopting these changes, reproductive torts would be much more certain and clearly identify what the harm is, to whom it occurred, and how to remedy or compensate someone for the harm caused. It would also remove the need for the courts to answer questions relating to the value of beings that are brought into existence.

The fundamental problems of comparing existence against non-existence and the impossibility of harming a potential person remain in all cases where a child is allowed to claim. We can now discuss and analyse these reproductive torts in turn, and through this process it will be shown that the considerations that are outlined here apply across

\footnotetext{
${ }^{34}$ Heyd, Genethics p.30.

${ }^{35}$ L. Davis, The Disability Studies Reader (Routledge, London 2010).
} 
jurisdictions, because it is the very nature of allowing children to claim under reproductive torts that gives rise to the problems plaguing the courts and the injustice of creating liability when harm cannot occur.

\section{Wrongful birth}

Wrongful birth claims operate on the basis that actual persons, the parents, sought some medical intervention which was carried out incorrectly and thus were denied the option to abort or prevent the conception of a child. The parents therefore seek damages from the medical provider at fault for the harm they have suffered. The only divergence from this definition in UK law is that the CDCLA allows offspring to claim for a wrongful birth as well as the parents in some circumstances ${ }^{36}$.

In the UK the concept of wrongful birth is embodied in case law and legislation $^{37}$, and includes liability for procedures during infertility treatment. Wrongful conception claims in the UK are subsumed under the title of wrongful birth cases, thus wrongful conception cases will hereafter be included in the term wrongful birth. However, the CDCLA only deals with situations where something affects the mother or offspring such as physical assault, inaccurate medical advice or a failure to diagnose a disability causing medical condition; basically this covers situations where offspring are "born with disabilities which would not otherwise have been present" ${ }^{38}$. Thus the event, in order to qualify under the CDCLA, has to be something that inflicts the disability upon what would otherwise be healthy offspring ${ }^{39}$. Currently it permits offspring to undertake legal action themselves against the medical provider.

\footnotetext{
${ }^{36}$ CDCLA 1976 s.1A.

${ }^{37}$ CDCLA 1976 s.1; MacFarlane v Tayside Health Board [2000] 2 AC 59; Whitehouse v Jordan [1981] W.L.R. 246;

Parkinson v St James and Seacroft University Hospital [2001] EWCA Civ 530.

${ }^{38}$ CDCLA s.1(2)(b).

${ }^{39}$ CDCLA s.1(2).
} 
One of the most prominent wrongful birth cases (although it would be known as a wrongful conception case elsewhere) is McFarlane $v$ Tayside Health Board ${ }^{40}$. This case established that parents may launch a wrongful birth claim when they would not have become pregnant but for negligence on the part of the medical organisation. In McFarlane the husband underwent a vasectomy which was unsuccessful and as a result his wife became pregnant. The House of Lords (now the Supreme Court) held that while it would be unjust to have the costs of healthy offspring compensated for, it was fair to have the health authority pay for the damage and distress of an unexpected pregnancy. In a later wrongful birth case, Parkinson v St James and Seacroft University Hospital NHS Trust ${ }^{41}$, the Court of Appeal held that a couple could recover the cost of an unwanted pregnancy due to the failure of a sterilisation procedure and the cost of special care due to the disabilities of their offspring. However the court refused to extend the coverage of McFarlane to cover general costs of raising a 'normal' child, therefore restricting compensation to distress and disability. Thus parents can claims for the costs and distress of a pregnancy and the costs of a disability if they are caused by a fault of the medical provider. This is because their interests, rights and goals have been damaged and frustrated by the wrongful action. Although, of course, strictly speaking the normal costs of raising the child should be included, they are excluded on the basis that the birth of a healthy child should not be recoverable because "society itself must regard the balance as beneficial. It would be repugnant to its own sense of values to do otherwise. It is morally offensive to regard a normal, healthy baby as more trouble and expense than it is worth" ${ }^{42}$. This rejection is thus based upon the interests of actually existing persons in promoting and

\footnotetext{
${ }^{40}$ MacFarlane v Tayside Health Board [2000] 2 AC 59.

${ }^{41}$ Parkinson v St James and Seacroft University Hospital [2001] EWCA Civ 530.

${ }^{42}$ MacFarlane v Tayside Health Board [2000] 2 AC 59, per Lord Millett p.114.
} 
valuing the production of children; it is not based on any supposed interests that potential people may have.

This approach has also been taken in some parts of the United States where "in virtually all cases, courts have awarded the plaintiff mothers ... medical expenses and emotional distress damages" 43 and have rejected damages for the "cost of raising the unexpected child to adulthood" 44 . However unlike in the UK, claims by disabled offspring, like those under the CDCLA, are dealt with differently. In New Jersey case of Gleitman $v$ Cosgrove $^{45}$ a child was born with defects after the mother contracted rubella, and received incorrect medical advice that rubella did not pose a risk to the foetus ${ }^{46}$. When the child was born the parents brought a claim of wrongful birth, matching the situation in the UK, but the child brought a claim of wrongful life not of wrongful birth thus the court permitted a direct claim by the child that more closely matches wrongful life cases in the $\mathrm{UK}^{47}$. The case of wrongful life will be considered in the subsequent section, but the divergence should be noted.

There is also the issue regarding the extent to which parents are entitled to information regarding their pregnancy. The relationship between information access about an embryo's genetic condition is discussed by Rosamund Scott in her analysis of the relationship between abortion and wrongful birth ${ }^{48}$. That is in the UK law only serious conditions can justify abortion ${ }^{49}$, so according to Scott in the UK medical

\footnotetext{
${ }^{43} \mathrm{~W}$. Hensel 'The disabling impact of wrongful birth and wrongful life actions' Harvard Civil Rights-Civil Liabilities Law Review 40 (2005) pp.141-195, p.151.

${ }^{44}$ Hensel, Actions p.151.

${ }^{45}$ Gleitman v Cosgrove [1967] 49 N.J. 22.

${ }^{46}$ Hensel, Actions p.155.

${ }^{47}$ Hensel, Action p. 155.

${ }^{48}$ R. Scott 'Prenatal screening, autonomy and reasons: the relationship between the law of abortion and wrongful birth' 11Medical Law Review (2003) pp.265-325.

${ }^{49}$ Abortion Act [1967] s.1(1)(d).
} 
providers only have to convey information when it relates to a serious condition. For example, if parents would abort on the basis of their embryo having a serious medical condition and the medical provider failed to give them that information that would allow a claim of wrongful birth ${ }^{50}$. If however the information relates to something trivial, say webbed toes, then the parents cannot claim that they would have aborted on that basis and that they should have been informed.

Under the psychological personhood approach suggested here, the embryo would have no standing and so the parents could terminate whenever they wish for whatever reason, even trivial ones. Thus the adoption of psychological personhood would also necessitate a change in abortion law to complete permissibility. Currently the decision of what satisfies the criterion of seriousness is "based upon the profession's assessment of the incidence of the risk and its seriousness," ${ }^{51}$ but this would no longer be the case because the seriousness of the condition would be irrelevant. There is a strong link between the information provided and the exercising of the right (in the USA) or opportunity (in the UK) to abort; or failing that opportunity suing the medical provider for a wrongful birth. Thus, under the approach proposed here the medical provider would have no justification for withholding information because it is only the interests of the parents that matter; the embryo has no claims to assert against the parents. Thus withholding information that the parents would have aborted on, as the parents are no longer constrained by the 'seriousness' criterion, could lead to a wrongful birth suit. This would greatly increase the scope and power of parental reproductive autonomy and change the law of and relating to abortion ${ }^{52}$.

\footnotetext{
${ }^{50}$ Scott, Birth pp.365-325.

51 Scott, Birth p.298.

52 Abortion will not however be discussed further in this article but this digression demonstrates the wider implications of psychological personhood.
} 
As stated earlier, wrongful conception/birth claims are based on the harms are clearly suffered by actual persons to their interests, and would therefore not need to be changed. The basis of wrongful conception/birth claims is coherent and clearly assigns harm and damage both theoretically and legally. However the exception which allows offspring to sue under the CDCLA ${ }^{53}$ must be abolished because it violates the principle that potential persons cannot be harmed by actions which are responsible for constituting their existence. Moreover it the parties involved are in a direct, connected single legal relationship ${ }^{54}$ because the child does not exist at the time the 'harm' is caused. It would also prevent parents from being liable to their offspring, and explain why the current refusal to recognise such liability makes sense because it is only parental interests that count. No claims of harm can be recognised in law because persons exist only as a result of those actions. For the most part the law of wrongful conception/birth would remain as it is but on the sole basis of harms to the interests of the parents (actual persons) and without the aberration of the CDCLA.

\section{Wrongful Life}

Wrongful life claims are made on the basis that the child who exists does so only because the women was denied a termination through the fault of the medical provider and that the child's life is so full of suffering that it should not exist. Unlike wrongful conception/birth cases, wrongful life cases are brought by the child themselves not their parents. The essential claim of wrongful life is that the offspring would have been better off not existing. In such cases, the suit for compensation is brought in the name of a (typically) severely disabled child who claims that 'but for' the negligence of the medical provider, they would not have been born at all. This creates a conceptual problem of

\footnotetext{
${ }^{53}$ CDCLA 1976 s.1A.

${ }^{54}$ Weinrib, Formalism, p.588.
} 
comparing something with the absence of everything. As Steininger ${ }^{55}$ points out wrongful life claims try to assess the damage inflicted upon offspring from living but do not have an alternative which would be worse as the courts are not prepared to compare existence to non-existence ${ }^{56}$. Even if the courts were prepared to make such a comparison, it is not clear how such a comparison could be made.

The case of McKay v Essex Area Health Authority ${ }^{57}$ made it clear that under UK law no offspring can sue for wrongful life. Stephenson LJ stated that it is "contrary to public policy, which is to preserve human life, to give a child a right not to be born except as whole, functional being" and that it is "impossible to measure the damages for being born with defects" ${ }^{\text {". }}$. Ackner LJ also says that "that there are ... [no damages] in any accepted sense" ${ }^{59}$. More forcefully Griffiths LJ stated that "I have come to the firm conclusion that our law cannot recognise a claim for "wrongful life" ${ }^{60}$ for the "most compelling reason ... is the intolerable and insoluble problem it would create in the assessment of damages" ${ }^{\prime 61}$. Thus wrongful life claims have been excluded from English law for two main reasons; firstly that it is against public interest to compare existence with non-existence, and secondly that no damages can be calculated because of the impossibility of comparing loss against not existing. As Ackner LJ stated "no comparison is possible and therefore no damage can be established which a court could recognise" ${ }^{\prime 62}$.

McKay was decided before the introduction of the CDCLA but even if that had been in force, such a claim would still have been rejected. As Brazier and Cave put it,

\footnotetext{
${ }^{55}$ B. Steininger 'Wrongful birth and wrongful life: basic questions' (2010) 1 JETL 125

${ }^{56}$ Steininger, Questions p.152.

${ }^{57}$ McKay v Essex Area Health Authority [1982] QB 1166.

${ }^{58}$ Mckay [1982] p.1184.

${ }^{59}$ McKay [1982] p.1189.

${ }^{60}$ McKay [1982] p.1190.

${ }^{61}$ McKay [1982] p.1192

${ }^{62}$ McKay [1982] p.1189.
} 
"[w]here the essence of the claim is that the child should never have been born at all, it lies outside the scope of section 1(2)(b)" of the CDCLA ${ }^{63}$. More than simply being outside the technical remit of the Act, the Court of Appeal ruled out wrongful life claims because they were against public policy, being a violation of the sanctity of life. Although the sanctity of life is not relevant here, because actions creating potential persons create the life that would be protected by sanctity, accepting life as a potential damage would necessitate "an 'existence/nonexistence' comparison ${ }^{64}$. This would be impossible because the court, or indeed anyone, is not capable of determining damages from an assessment which involves comparing existence and non-existence, thus no cause of action was possible ${ }^{65}$. This view is matched almost exactly in Germany where the Federal Constitutional Court (Bundesverfassungsgericht) stated that "the child's existence cannot, in law, be classified as damage" ${ }^{96}$ (Schwangerschaftsabbruch II [1993]).

However this strict logical approach has not always been taken. Rosamund Scott, whilst accepting the logical argument regarding existence/non-existence, "that there was no-one or no being who could experience non-existence" ${ }^{97}$, argues that this framing of wrongful life claims misses the point. Scott suggests that the issue of wrongful life claims "lies in being born under certain conditions, namely when the burdens of life ... are so severe that they outweigh any compensating goods" ${ }^{68}$. This view is similar to the one held by Kirkby $\mathrm{J}$ who believes that it is the suffering in wrongful life cases that should be given prominence, even going so far as to argue that "a life of severe and unremitting suffering

\footnotetext{
${ }^{63}$ Brazier and Cave, Law p.321; CDCLA 1976.

${ }^{64}$ Priaulx 'Conceptualising harm in the Case of the Unwanted Child' European Journal of Health Law 9(2002) pp.337-359.

${ }^{65}$ McKay v Essex Area Health Authority [1982] QB 1166.

${ }^{66}$ Schwangerschaftsabbruch II [1993] BVerfGE 88, 203

${ }^{67}$ Scott, Anomalies p.129.

${ }^{68}$ Scott, Anomalies p.130.
} 
is worse than non-existence" ${ }^{69}$. In Curlender v Bio-sciences Laboratories [1980] Jefferson P.J. claimed that the claimant "both exists and suffers, due to the negligence of others"

In the French case of Perruche we can see this suffering-orientated approach at work. The child was allowed to "sue his mother's doctors because they failed to diagnose his condition while she was pregnant, [thus] denying her the choice of an abortion" ${ }^{, 71}$. The Cour de Cassation stated that "the issue is not his [the offspring's] birth but his disabilities" ${ }^{72}$. The subsequent public outrage at this decision resulted in the introduction of a new provision in the code de l'action sociale et des familles section L114-5 which prohibits offspring bringing a claim where they would not otherwise exist and consequently only parents can now bring a claim under French law ${ }^{73}$. We can thus see that the idea that life itself could be considered 'damage' and thus be a cause of action in law was considered unacceptable. Scott's rejoinder would be that it is the suffering not the life that is compensated for, however this author would still argue that this would fall foul of the 'actions constituting existence' problem.

In contrast, in the state of California there was a drift, albeit haphazardly, towards a recognition of a child's standing to sue. Wendy $\mathrm{Hensel}^{74}$ provides a clear breakdown of the Californian court's decisions and reasoning regarding wrongful life. One of the earliest US cases was the previously mentioned case of Gleitman $v$ Cosgrove which found that because it was "logically impossible" to "measure the difference between life with defects against the utter void of non-existence" wrongful life claims could not be

\footnotetext{
${ }^{69}$ Harriton v Stephens [2006] Unreported Cases High Court of Australia at [105].

${ }^{70}$ Curlender v Bio-sciences Laboratories [1980] 165 Cal. Rptr. 477 p.488.

${ }^{71}$ Priaulx, Child pp.339-340.

${ }^{72}$ Epx Perruche c/ Mutuelle d'assurance du corps sanitaire francais et al. (Cour de Cassation) [2000] JCP 2000 II 10438.

${ }^{73}$ Priaulx, Child p.340; The New York Times, October 19, 2001, Code de l'action sociale et des familles (amended to include section L114-5 in 2002).

${ }^{74}$ Hensel, Actions.
} 
recognised ${ }^{75}$ thus reflecting the position most commonly held in judicial systems. This all changed however in the Californian case of Curlender v Bio-Science Laboratories where the Court of Appeal of California allowed offspring to claims for damages relating to "damages for the pain and suffering to be endured ... and any special pecuniary loss resulting from the plaintiff's condition" ${ }^{76}$. Interestingly the court felt that there was "no sound public policy reason which should protect those parents from being answerable for the pain, suffering and misery which they have wrought upon their offspring", ${ }^{\text {, }}$. Thus in some ways the Californian approach here is the most consistent because it allows 'harmed' offspring to claim against all those who brought it into existence; although the basis itself of such a claim is here rejected.

This prompted a swift response from the Californian state legislature to protect parents from such a claim ${ }^{78}$. Shortly thereafter the California Supreme Court in Turpin v Sortini confirmed that the sanctity of life did not preclude claims of wrongful life, and allowed damages for "significant medical and financial burden"79 but rejected claims for general damages relating to the normal costs of existence. The claim for general damages was rejected "because the plaintiff never had a chance to of being born without her affliction, and it would be impossible to ascertain the extent of an injury in this context" $"$. However in most other cases the "courts [in the USA] have consistently rejected wrongful life actions" reasoning that "life burdened with defects is better than no life at all and ... that the ... child suffered no legally cognisable injury in being born"

\footnotetext{
${ }^{75}$ Hensel, Actions p.155.

${ }^{76}$ Curlender v Bio-sciences Laboratories [1980] 165 Cal. Rptr. 477 p.488.

${ }^{77}$ Curlender [1980] p.487

${ }^{78}$ The Civil Code of the State of California, California (1873) s.43.6.

${ }^{79}$ Turpin v Sortini [1982] 31 Cal. 3d 220 p.238.

${ }^{80}$ Hensel, Actions p.160.
} 
thus "damages are incalculable" ${ }^{81}$. The exceptions (Curlender and Turpin) in California however "have concluded instead that life is not always preferable to non-existence" 82 or that damages are incalculable ${ }^{83}$.

Rosamund Scott reaches a similar conclusion, after reviewing the arguments set out by Kirkby J in Harriton v Stephens, Jefferson P.J. in Curlender v Bio-sciences Laboratories and the combined judgement in Perruche, regarding how life should be treated in these situations. Scott claims that "while it may be helpful to emphasise suffering rather than life per se ... care has to be taken that the condition ... be so severe that life will be of sub-zero quality" ${ }^{\prime 84}$. Thus Scott's suggestion is that severity is taken as the basis of wrongful life claims and when a severe enough condition occurs, then a wrongful life claim can be brought against the medical provider. Furthermore, Scott argues that the deployment of the existential threshold in these cases is a legal construction providing a barrier against wrongful life claims. She suggests that "emphasising that non-existence cannot be known is ultimately unhelpful, or besides the point ... and loses sight of ... the normative role of the construct of non-existence" ${ }^{\text {} 85}$. Thus Scott is essentially arguing that justice has lost out to logic.

However Scott's suggestion is rejected by this author for two reasons. Firstly, the issue of existence-non-existence is crucial because it is this threshold that limits legal actions to those incidents which are cognisable. If we were to accept that non-existence was not a boundary to legal action, then we may be placed in the invidious position of having to take into consideration potential liability owed to people who may never exist. Thus the legal prohibition on potential persons from being able to claim, in this case in

\footnotetext{
${ }^{81}$ Hensel, Actions p.161.

${ }^{82}$ Hensel, Actions p.162.

${ }^{83}$ Civil Code, California (1873) s.43.6.

${ }^{84}$ Scott, Anomalies p.133.

${ }^{85}$ Scott, Anomalies p.142.
} 
reproductive torts, should stand. Moreover, the importance of the logical existential distinction should not be underestimated, as it relates to whether harms have occurred at all and to the existence of a correlative relationship between 'harmer' and 'harmed'.

This leads directly into the second objection to Scott's proposal. If we accept Scott's suggestion, and allow offspring to claim for actions that occur before their existence and use a severity threshold to avoid open-ended exposure to liability just mentioned, this would mean that wrongful life claims are permitting legal action where no harm to the offspring has occurred. It would thus be fundamentally unjust to allow medical providers to be liable for actions which create the particular person who is claiming against them. Medical providers would remain liable to the parents who they failed to treat with the requisite standard of care, but they would not (and should not) be liable to the offspring for creating them. Under the theory of psychological personhood set out here, the action which creates a particular person, that is the act that creates a factual as opposed to merely potential person, cannot be a harmful act to the person created. Thus, cases where wrongful life claims have been recognised should not form the basis of law and should be rejected because they rely on the false premise that life is comparable to non-existence and that those actions which constitute the existence of a person can be classified as beneficial or harmful.

Additionally, the struggle with wrongful life claims, and in some cases recognising them, is down to financial considerations and distributive justice concerns. If there is no liability with the medical provider for disabled children then the costs of their care cannot be taken from the medical provider but must come from another source. The possibility of suing their parents may provide another source of financial security, but practical considerations regarding the payment of damages may prevent claims against parents as they are likely to already be bearing the costs (or some of the costs) but it would be theoretically possible as demonstrated by Californian case of Curlender $v$ Bio- 
Sciences Laboratories. Moreover, as Scott mentions, parental liability would directly conflict with the mother's "self-determination and bodily integrity" 86 and thus parental liability should be opposed for this reason as well. It thus seems (in the USA at least) that the acceptance of claims was aimed at ensuring some financial provision was in place for the care of the disabled child; this is comparable to the French court allowing the child to sue directly in Perruche.

However this paper has concluded that actions which create people cannot be a cause of legal action because being caused to exist cannot be a harm or damage because it is impossible for someone to be harmed by factors constitutive of their existence and identity. Once the child is an actual person, and thus the necessary pre-conditions for them to have interests is met, society (that is the actual persons who make up the social and political entity in which the disabled child lives) do have an obligation to the child, as an actual person. Thus, society must make provision for disabled persons and this can be achieved through general taxation, a welfare system, public healthcare and so on. The child does not have to be able to sue medical providers who cause their existence in order to be financially supported, and indeed it has been argued here that children should not and cannot sue those who cause them to exist.

\section{Conclusion}

This article has analysed the basis of reproductive torts wrongful conception/birth and wrongful life through the application of the potential/actual person distinction. The law in the UK, and in other jurisdictions, on wrongful conception/birth are primarily based upon the interests of the parents who have suffered some loss or harm. This is the only sound basis for these torts. Difficulties and problems arise with wrongful life claims and

\footnotetext{
${ }^{86}$ Scott, Anomalies p.148.
} 
when wrongful conception/birth claims stray into being claims of the child (as under the CDCLA in the UK). Claims by the child try to bridge the potential/actual divide and thus allow claims against the medical provider for actions which constitute their very existence. This has been shown to be logically impossible as the person-affecting nature of torts requires that a subject exists who could have been in a better condition. However, when we are discussing actions that cause the existence of a person then the absence of that action results in their nonexistence, not their existence in a better state. This argument is clearly articulated when Heyd states that nonexistence is "not a state that can be attributed to a subject" ${ }^{87}$. Consequently the use of personal harm as the basis of reproductive torts has been ruled out as persons cannot be harmed by actions which change who will exist. This means that no potential person has or can claim an interest or a right in either existing or existing in a particular condition.

As the better or worse condition of a subject is a requirement of reproductive torts, a child who results from the actions, however wrongful, cannot be permitted by the law because it contradicts the internal coherence of tort claims. Coherence is important because it allows those subject to the legal system to predict what conduct is permissible and what is not. This knowledge is achieved by the consistent application of the justification used to in setting out the law. As Weinrib states the law is "not merely a collection of posited norms or an exercise of official power but a social arrangement responsive to moral argument" ${ }^{88}$. Weinrib's suggests that the "[l]aw connects one person to another through the ensemble of concepts, principles, and processes that come into play when a legal claim is asserted" ${ }^{89}$. However in order for the law to fulfil its function as a set of laws that can successfully be followed, these "concepts, principles and

\footnotetext{
${ }^{87}$ Heyd, Genethics p.30.

${ }^{88}$ Weinrib, Formalism, p.583.

${ }^{89}$ Weinrib, Formalism, p.584.
} 
processes" ${ }^{90}$ must be internally compatible with each other. As we have seen in the case of reproductive torts, attempts to deal with claims by or the behalf of children have been inconsistent and at times contradictory.

Such inconsistency arises because reproductive torts do no conform they the justification for the existence. That is the crucial relationship requirement whereby "the plaintiff and the defendant [are treated] as correlative to one another" ${ }^{\prime 11}$ is absent. If reproductive torts are an instrument of "corrective justice" crucial justification for the existence of reproductive torts in the first place. More importantly as this relationship is the justificatory basis of reproductive tort claims then it should inform the structure of tort claims.

When this relationship is not present then reproductive tort claims cannot be sustained, and in the case of potential persons this requirement is never fulfilled. Thus the structures of reproductive torts are an ad hoc construction rather than a sound coherent and above all justified systematic claim. The changes to reproductive torts set out here are thus a response to this incoherence based upon the consistent application of the justificatory theory of persons aimed at forging a "harmonious interrelationship among the constituents" ${ }^{\prime 93}$ of reproductive torts.

The current approach of tort law in judging harm and damage through comparisons between the conditions the person would have been in and the condition they actually are in, is correct because it requires that an actual persons exist who is affected; thus tort law is person-affecting in its approach. However, allowing children to claim under any reproductive torts must logically be prohibited. In the case of the UK, the current rejection of wrongful life claims must be maintained but the CDCLA must be

\footnotetext{
${ }^{90}$ Weinrib, Formalism, p.584.

91 Weinrib, Formalism, p.593.

92 Weinrib, Formalism, p.593.

${ }^{93}$ Weinrib, Formalism, p.593.
} 
repealed or reformed to prevent children claiming under the wrongful birth tort. Parents must be able to claim on the basis of negligence or misconduct on the part of medical professionals because they are harmed; their interests and rights at the time are affected and harmed. They (as actual persons) could have been in a better situation than the ones they find themselves in. Thus parents and the harm they have suffered can be, and is, the correct basis of reproductive tort claims.

In conclusion this paper advocates a modest legal reform, namely amending the CDCLA to prevent claims by children when actions cause disabilities, but it provides arguments both to engender this reform and to maintain the rejection of any claims by children under reproductive torts (and under wrongful life in particular). The implications of the arguments presented here, both in relation to the law and to the moral and ethical basis of claims, have farther reaching implications in other reproductive issues such as genetic modification, abortion and procreative decisions as in all cases the potential person cannot be the basis of any claims or restrictions on the conduct of the prospective parents. Only the effects on other actual persons or the conduct of the parents themselves (for example on the basis of virtue ethics or a standard of behaviour) can ground legal sanction. Particularly as these different individuals can form correlative relationships with each other that potential and actual persons cannot. These wider implications are beyond the scope this article, and thus would need to be (and deserve to be) considered in separate papers. For the moment this paper concludes with the desirability of reforming the Congenital Disabilities Act suggested earlier and the rejection of any claims by children for actions that are responsible for their existence, because potential persons cannot be affected by actions bringing them to existence. Basically it comes down to this; there is no justification for creating medical provider liability to the offspring for actions which constitute the offspring's very existence. 


\section{Acknowledgements:}

I would like to thank Professors Søren Holm and Mätti Hayry for their comments regarding this article, and the reviewers for their constructive comments. 